STRUCTURAL SCIENCE CRYSTAL ENGINEERING MATERIALS

ISSN 2052-5206

Received 27 June 2018

Accepted 14 November 2018

Edited by J. Lipkowski, Polish Academy of Sciences, Poland

Keywords: uranyl sulfates; crystal structure; Shannon information; structural complexity; topological complexity; ladder diagrams.

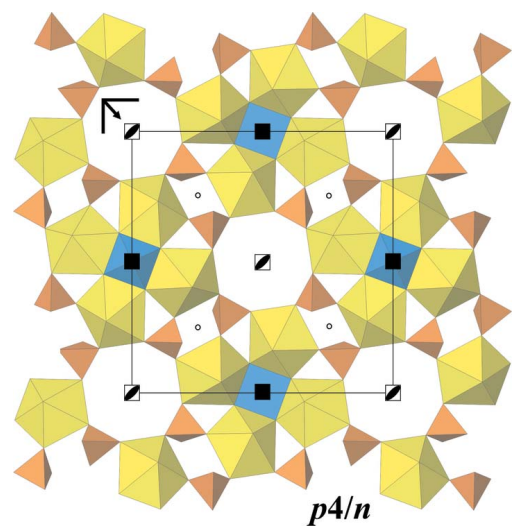

(C) 2019 International Union of Crystallography

\section{Structural complexity of natural uranyl sulfates}

\author{
Vladislav V. Gurzhiy ${ }^{\mathrm{a}}$ and Jakub Plášil ${ }^{\mathrm{b} *}$
}

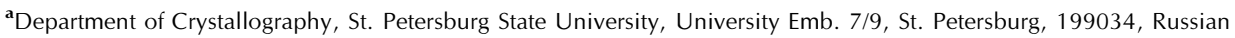
Federation, and ${ }^{\mathbf{b}}$ Institute of Physics ASCR, v.v.i., Na Slovance 2, Praha 8, 18221, Czech Republic. *Correspondence e-mail: plasil@fzu.cz

Uranyl sulfates, including those occurring in Nature ( $\sim 40$ known members), possess particularly interesting structures. They exhibit a great dimensional and topological diversity of structures: from those based upon clusters of polyhedra to layered structures. There is also a great variability in the type of linkages between $\mathrm{U}$ and $\mathrm{S}$ polyhedra. From the point of view of complexity of those structures (measured as the amount of Shannon information per unit cell), most of the natural uranyl sulfates are intermediate (300-500 bits per cell) to complex (500-1000 bits per cell) with some exceptions, which can be considered as very complex structures ( $>1000$ bits per cell). These exceptions are minerals alwilkinsite-(Y) (1685.95 bits per cell), sejkoraite-(Y) (1859.72 bits per cell), and natrozippeite (2528.63 bits per cell). The complexity of these structures is due to an extensive hydrogen bonding network which is crucial for the stability of these mineral structures. The hydrogen bonds help to propagate the charge from the highly charged interlayer cations (such as $\mathrm{Y}^{3+}$ ) or to link a high number of interlayer sites (i.e. five independent $\mathrm{Na}$ sites in the monoclinic natrozippeite) occupied by monovalent cations $\left(\mathrm{Na}^{+}\right)$. The concept of informational ladder diagrams was applied to the structures of uranyl sulfates in order to quantify the particular contributions to the overall informational complexity and identifying the most contributing sources (topology, real symmetry, interlayer bonding).

\section{Introduction}

Naturally occurring uranyl sulfates are important phases both from the mineralogical and the environmental point of view. Assemblages of uranyl sulfate minerals are common in oxidized parts of uranium deposits worldwide. They form via the oxidation-hydration weathering of primary uranium minerals, mainly uraninite, which interact with acid solutions derived from the decomposition of sulfides, such as pyrite or chalcopyrite (Finch \& Murakami, 1999; Krivovichev \& Plášil, 2013; Plášil, 2014). The alteration of primary uranium ores under the low $\mathrm{pH}$ generates highly mobile acid solutions, containing dissolved $\mathrm{UO}_{2}{ }^{2+}$ as $\mathrm{UO}_{2}-\mathrm{SO}_{4}$ aqueous complexes, which yields a considerable environmental impact, especially around the old mining sites (Fernandes et al., 1995; Brugger $e t$ al., 2003; Johnson, 2003; Johnson \& Hallberg, 2005). Uranyl sulfates show a great structural diversity (Krivovichev, 2010; Krivovichev \& Plášil, 2013) arising from combinatorial and topological possibilities of linkage of the basic structural elements, uranyl coordination polyhedra and sulfate tetrahedra, which leads to a large variety of topological and 


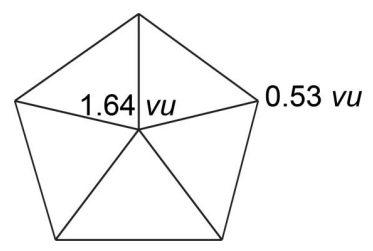

Figure 1

Graph representation of the uranyl pentagonal bipyramid, $\mathrm{UO}_{7}$, with displayed bond-valence sums (in valence units, $v u$ ) at particular $\mathrm{O}$ sites (vertices of the graph).

geometrical isomers. Herein, we would like to characterize and quantify the topological and structural complexity parameters for one of the most representative groups of supergene uranium minerals - uranyl sulfates. We have used the clusters

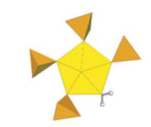

belakovskiite

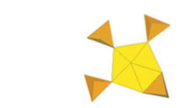

klaprothite/péligotite

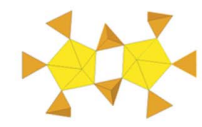

bluelizardite

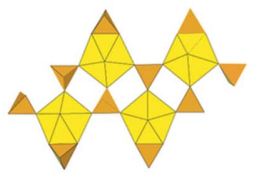

ottohahnite chains

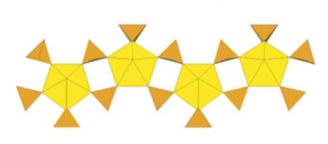

fermiite/meisserite

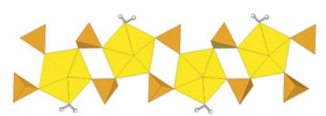

oppenheimerite/bobcookite/ rietveldite

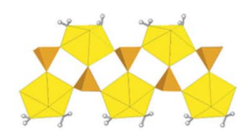

shumwayite

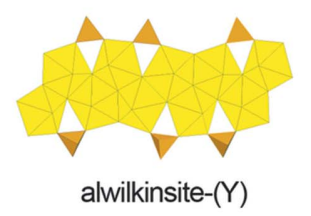

alwilkinsite-(Y)

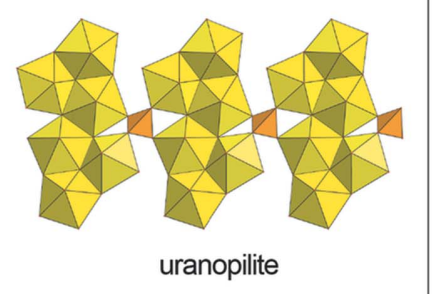

approach recently developed by S. V. Krivovichev (Krivovichev, 2012, 2013, 2014, 2018), which allows the crystal structures to be characterized in terms of the information content.

\section{Natural uranyl sulfates and their crystal structures}

Hexavalent uranium in the solid state is most frequently present as a (nearly) linear uranyl ion, $\mathrm{UO}_{2}{ }^{2+}(U r)$, in which the bond-valence requirements of strongly bonded $\mathrm{O}$ atoms are almost satisfied (Fig. 1). Therefore, the bonding of additional elements takes place via ligands arranged in the equatorial planes of uranyl coordination polyhedra. In the case of uranyl sulfates, it goes exclusively about the uranyl pentagonal bipyramid, $\mathrm{UO}_{2} \Phi_{7}$ (where $\Phi=\mathrm{O}^{2-}, \mathrm{OH}^{-}, \mathrm{H}_{2} \mathrm{O}$ ). Sulfur is tetrahedrally coordinated as an $\mathrm{SO}_{4}$ tetrahedron and the linkage between $\mathrm{U}^{6+}$ and $\mathrm{S}^{6+}$ polyhedra is usually monodentate (with exceptions, see below). Polymerization of basic units leads to chain (10) or sheet (23) structures, which prevail over structures. There are fewer structures based upon isolated clusters of polyhedra (5). To date, 38 well characterized uranyl sulfates are known from Nature. Their overview and basic structural and chemical properties are reported in Table 1 as well as displayed in Fig. 2.

\section{Complexity calculations}

In order to evaluate the influence of various crystal-chemical factors (such as dimensionality of the uranium-bearing units and their hydration state) on the structure and symmetry of uranyl sulfate complexes and on the structural architecture of minerals in general, the structural and topological complexity was studied in terms of the information-based approach developed by Krivovichev (2012, 2013, 2014) and recently used by Cempírek et al. (2016), Gurzhiy et al. (2016, 2017, 2018a, b), Krivovichev et al. (2016, 2017), Majzlan et al. (2018) and Plášil (2018a,b). The structural complexity is quantitatively estimated as a Shannon information content per atom $\left(I_{G}\right)$ and per unit cell $\left(I_{G \text {,total }}\right)$. The amount of Shannon information reflects diversity and relative proportion of different objects, e.g.

Figure 2

Structural units of natural uranyl sulfates. Color scheme: $\mathrm{UO}_{7}$ is yellow, $\mathrm{SO}_{4}$ is orange, the $\mathrm{H}$ atoms are displayed as black-and-white ball and stick. 
Table 1

Overview of natural uranyl sulfates and their basic characteristics.

\begin{tabular}{|c|c|c|c|c|}
\hline $\begin{array}{l}\text { Structural } \\
\text { units }\end{array}$ & Mineral & Chemical formula & $\begin{array}{l}\text { Space } \\
\text { group }\end{array}$ & Reference \\
\hline Clusters & $\begin{array}{l}\text { Belakovskiite } \\
\text { Bluelizardite } \\
\text { Klaprothite } \\
\text { Ottohahnite } \\
\text { Péligotite }\end{array}$ & $\begin{array}{l}\mathrm{Na}_{7}\left(\mathrm{UO}_{2}\right)\left(\mathrm{SO}_{4}\right)_{4}\left(\mathrm{SO}_{3} \mathrm{OH}\right)\left(\mathrm{H}_{2} \mathrm{O}\right)_{3} \\
\mathrm{Na}_{7}\left(\mathrm{UO}_{2}\right)\left(\mathrm{SO}_{4}\right)_{4} \mathrm{Cl}\left(\mathrm{H}_{2} \mathrm{O}\right)_{2} \\
\mathrm{Na}_{6}\left(\mathrm{UO}_{2}\right)\left(\mathrm{SO}_{4}\right)_{4}\left(\mathrm{H}_{2} \mathrm{O}\right)_{4} \\
\mathrm{Na}_{6}\left(\mathrm{UO}_{2}\right)_{2}\left(\mathrm{SO}_{4}\right)_{5}\left(\mathrm{H}_{2} \mathrm{O}\right)_{8.5} \\
\mathrm{Na}_{6}\left(\mathrm{UO}_{2}\right)\left(\mathrm{SO}_{4}\right)_{4}\left(\mathrm{H}_{2} \mathrm{O}\right)_{4}\end{array}$ & $\begin{array}{l}P \overline{1} \\
C 2 / c \\
P 2_{1} / c \\
P \overline{1} \\
P \overline{1}\end{array}$ & $\begin{array}{l}\text { Kampf et al. }(2014) \\
\text { Plášil et al. }(2014 a) \\
\text { Kampf } \text { et al. }(2017 b) \\
\text { Kampf et al. }(2017 b) \\
\text { Kampf } \text { et al. }(2017 b)\end{array}$ \\
\hline Chains & $\begin{array}{l}\text { Adolfpateraite } \\
\text { Alwilkinsite-(Y) } \\
\text { Bobcookite } \\
\text { Fermiite } \\
\text { Meisserite } \\
\text { Oppenheimerite } \\
\text { Shumwayite } \\
\text { Svornostite } \\
\text { Uranopilite } \\
\text { Wetherillite }\end{array}$ & $\begin{array}{l}\mathrm{K}\left(\mathrm{UO}_{2}\right)\left(\mathrm{SO}_{4}\right)(\mathrm{OH})\left(\mathrm{H}_{2} \mathrm{O}\right) \\
\mathrm{Y}\left[\left(\mathrm{UO}_{2}\right)_{3}\left(\mathrm{SO}_{4}\right)_{2} \mathrm{O}(\mathrm{OH})_{3}\right]\left(\mathrm{H}_{2} \mathrm{O}\right)_{14} \\
\mathrm{NaAl}\left(\mathrm{UO}_{2}\right)_{2}\left(\mathrm{SO}_{4}\right)_{4}\left(\mathrm{H}_{2} \mathrm{O}\right)_{18} \\
\mathrm{Na}_{4}\left(\mathrm{UO}_{2}\right)\left(\mathrm{SO}_{4}\right)_{3}\left(\mathrm{H}_{2} \mathrm{O}\right)_{3} \\
\mathrm{Na}_{5}\left(\mathrm{UO}_{2}\right)\left(\mathrm{SO}_{4}\right)_{3}\left(\mathrm{SO}_{3} \mathrm{OH}\right)\left(\mathrm{H}_{2} \mathrm{O}\right) \\
\mathrm{Na}_{2}\left(\mathrm{UO}_{2}\right)\left(\mathrm{SO}_{4}\right)_{2}\left(\mathrm{H}_{2} \mathrm{O}\right)_{3} \\
{\left[\left(\mathrm{UO}_{2}\right)\left(\mathrm{SO}_{4}\right)\left(\mathrm{H}_{2} \mathrm{O}\right)_{2}\right]_{2}\left(\mathrm{H}_{2} \mathrm{O}\right)} \\
\left.\mathrm{K}_{2} \mathrm{Mg}_{(}\left(\mathrm{UO}_{2}\right)\left(\mathrm{SO}_{4}\right)_{2}\right]_{2}\left(\mathrm{H}_{2} \mathrm{O}\right)_{8} \\
\left(\mathrm{UO}_{2}\right)_{6}\left(\mathrm{SO}_{4}\right) \mathrm{O}_{2}(\mathrm{OH})_{6}\left(\mathrm{H}_{2} \mathrm{O}\right)_{14} \\
\mathrm{Na}_{2} \mathrm{Mg}\left(\mathrm{UO}_{2}\right)_{2}\left(\mathrm{SO}_{4}\right)_{4}\left(\mathrm{H}_{2} \mathrm{O}\right)_{18}\end{array}$ & $\begin{array}{l}P 2_{1} / c \\
P 2_{1} 2_{1} 2_{1} \\
P \overline{1} \\
P m n 2_{1} \\
P{ }^{-1} \\
P \overline{1} \\
P 2_{1} / c \\
P m n 2_{1} \\
P \overline{1} \\
P 2_{1} / c\end{array}$ & $\begin{array}{l}\text { Plášil et al. }(2012 a) \\
\text { Kampf } \text { et al. }(2017 c) \\
\text { Kampf } \text { et al. }(2015 b) \\
\text { Kampf } \text { et al. }(2015 c) \\
\text { Plášil } \text { et al. }(2013 b) \\
\text { Kampf } \text { et al. }(2015 c) \\
\text { Kampf } \text { et al. }(2017 a) \\
\text { Plášil } \text { et al. }(2015 a) \\
\text { Burns }(2001) \\
\text { Kampf } \text { et al. }(2015 b)\end{array}$ \\
\hline
\end{tabular}

the number and relative proportion of different sites in an elementary unit cell of a crystal structure. For a crystal structure, the calculation involves the use of the following equations (Krivovichev, 2012, 2013, 2014):

$$
\begin{aligned}
& I_{G}=-\sum_{i=1}^{k} p_{i} \log _{2} p_{i}\left(\text { bits atom }{ }^{-1}\right), \\
& I_{G, \text { total }}=-v I_{G}=-v \sum_{i=1}^{k} p_{i} \log _{2} p_{i}\left(\text { bits cell }^{-1}\right),
\end{aligned}
$$

where $k$ is the number of different crystallographic orbits (independent crystallographic Wyckoff sites) in the structure and $p_{i}$ is the random choice probability for an atom from the $i$ th crystallographic orbit, that is:

$$
p_{i}=m_{i} v^{-1},
$$

where $m_{i}$ is a multiplicity of a crystallographic orbit (i.e. the number of atoms of a specific Wyckoff site in the reduced unit cell) and $v$ is the total number of atoms in the reduced unit cell.
The reliable correlation of complexity parameters is possible only for compounds with the same or very close chemical composition (e.g. polymorphs), whereas changes in hydration state could significantly change the complexity values. Analyzing the stability parameters of the minerals and possible mineral evolution trends, it is more reasonable to analyze topological and structural complexity of uranyl sulfate structural units as backbones of crystalline phases, whereas additional cations and water molecules occupying interlayer space can be excluded from the detailed consideration.

\section{Topological and structural complexity}

The information-based complexity parameters for the Ubearing units in the structures of uranyl sulfate minerals are given in Table 2. Calculations have been performed in several steps. Firstly, the structural complexity of the structural units has been analyzed, taking into account their real layer (RL) or rod group (RG) symmetries. Secondly, the topological complexity (according to the maximal symmetry group) has been calculated. Complexity parameters for the whole struc- 
Table 2

Natural uranyl sulfates and their complexity measures.

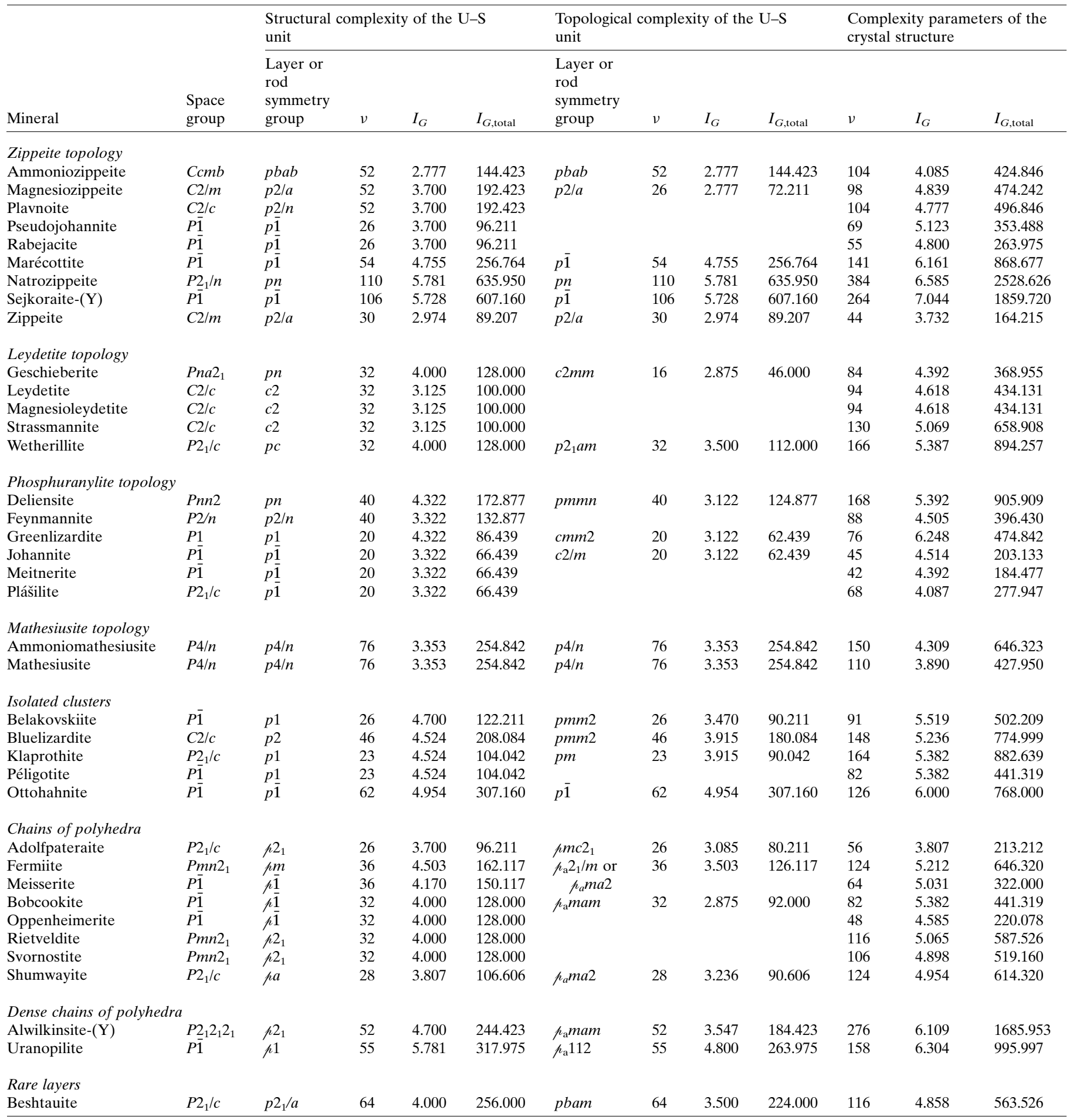

tures have been calculated using the TOPOS (Blatov et al., 2014) package and are given in Table 2 for comparison. It should be taken into account that all calculations were based on the original CIF files from the structural databases (Inorganic Crystal Structure Database and American Mineralogist Crystal Structure Database) and respective publications. In addition, positions of all $\mathrm{H}$ atoms have been assigned manu- ally (if these data were not reported in the original entries) considering the distribution of hydrogen-bonding system, which include traditional ranges of bond lengths and angles within the $D-\mathrm{H} \cdots A$ atoms (here, $D$ is a donor and $A$ is an acceptor; both are $\mathrm{O}$ atoms).

The complexity calculations have been undertaken for 38 uranyl sulfate minerals with well defined crystal structures. 
The most frequent value of structural complexity of the entire structure (including $\mathrm{H}$ atoms) is between 500 and 600 bits per cell (with an average of 629.49 bits per cell and a median of 485.84 bits per cell). The distribution of the complexity values is asymmetric, showing a positive skewness $(=2.431)$ (Fig. 3). The majority of uranyl sulfate structures should be considered as intermediate $(100-500$ bits per cell) to complex $(<1000$ bits per cell). Nevertheless, there are three exceptions, alwilkinsite-(Y) (Kampf et al., 2017c), sejkoraite-(Y) (Plášil et al., 2011a) and natrozippeite (Burns et al., 2003), that have very complex structures ( $>1000$ bits per cell) (Table 2). These structures are highly hydrated, either containing highly charged metal cations $\left(\mathrm{Y}^{3+}\right.$ and $\left.\mathrm{REE}^{3+}\right)$ or higher amounts of interstitial metal cations ( $c f$. natrozippeite contains five $\mathrm{Na}$ and eight $\mathrm{U}$, while magnesiozippeite contains one $\mathrm{Mg}$ and two U). Topological and structural complexities are described and discussed more in detail in the following text.

Crystal structures of belakovskiite, bluelizardite, klaprothite, péligotite and ottohahnite are based on the isolated uranyl sulfate structural units [Figs. $4(a)-4(d)$ ]. The structural unit of belakovskiite contains: one $\mathrm{U}$, four $\mathrm{S}$, two uranyl $\mathrm{O}, 16$ sulfate $\mathrm{O}$, one water $\mathrm{O}$ and two $\mathrm{H}$ orbits, all with multiplicities of 1 (taking into account its $p 1$ structural symmetry). In total, there are 26 orbits with onefold multiplicity (26 atoms). Structural complexity parameters for the uranyl sulfate unit in the structure of belakovskiite is calculated as $I_{G}=4.700$ bits per atom, $I_{G \text {,total }}=122.211$ bits per cell. In order to calculate the topological complexity parameters for the same unit, its maximal symmetry should be taken into account. The maximal symmetry of this topology is pmm2 (Fig. 4a), i.e. it is higher than the real symmetry. It is possible if sulfate tetrahedra have a mirror arrangement relative to the plane passing through the water molecule and $U r$, and if two non-shared $\mathrm{O}$ atoms of sulfate tetrahedra are arranged one above another along the $c$ direction, so the mirror plane would pass through the equatorial planes of uranyl bipyramids. In this case, the $v$ (number of atoms) is 26 , but the distribution of orbits will change into

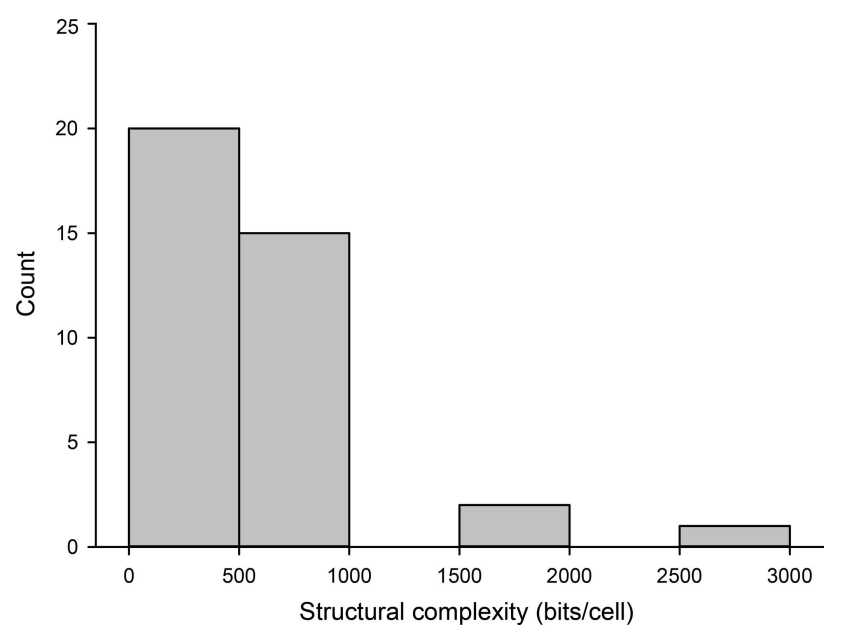

Figure 3

Histogram showing distribution of structural complexity values for 38 natural uranyl sulfates. another scheme: one $\mathrm{U}$ orbit with multiplicity of 1 ; one $\mathrm{S}$ orbit with multiplicity of 4; one $\mathrm{O}_{\mathrm{Ur}}$ orbit with multiplicity of 2; six $\mathrm{O}_{S}$ orbits with multiplicities of 2, 2, 2, 2, 4, 4; one $\mathrm{O}_{\mathrm{H} 2 \mathrm{O}}$ orbit with multiplicity of 1 ; one $\mathrm{H}$ orbit with the multiplicity of 2 . In total, there are two orbits with multiplicities of 1 , six orbits with multiplicities of 2 and 3 orbits with multiplicities of 4 . The topological complexity parameters for the uranyl sulfate units in the structure of belakovskiite are: $I_{G}=3.470$ bits per atom, $I_{G, \text { total }}=90.211$ bits per cell. Therefore, the structural information for the units in the structure of belakovskiite is higher than the topological information by a factor of $\sim 1.35$. The topological symmetry of uranyl sulfate isolated units in bluelizardite is also pmm2 (Fig. $4 b$ ) and the structural information is higher than the topological information by the factor of $\sim 1.15$. Isolated uranyl sulfate complexes in the structures of klaprothite and péligotite have rather low topological symmetry pm (Fig. 5c) due to the presence of three nonshared vertices at the sulfate tetrahedra trans-arranged relative to the edge-shared tetrahedra; thus, it is impossible for two mirror planes to be passed through them. The largest isolated complex among the uranyl sulfate minerals has been observed in the structure of ottohahnite (Fig. 4d). Due to the presence of two three-connected sulfate tetrahedra, two geometrical isomers could be possible. If the fourth nonshared vertices were to arrange $u p$ and down relative to the equatorial planes of the uranyl polyhedra as it is in the structure of ottohahnite, the topological symmetry would be $p \overline{1}$. If both vertices were arranged in one direction, topological symmetry would be $p 2$, which in fact wouldn't affect the complexity parameters, since the number of orbits and their multiplicity of 2 will be the same in both cases.

The symmetry of the infinite chains is considered in terms of rod group theory. The structural RG symmetry of all ten minerals, where structures are based on the rarefied (adolfpateraite, fermiite, bobcookite and shumwayite structural types) and dense [alwilkinsite-(Y), uranopilite] 1D uranyl sulfate complexes, is rather low and varies from $\mu 1$ to $p m$ [Figs. 4(e)-4(j)]. At the same time, the presence of one- and two-connected sulfate tetrahedra allows much higher orthorhombic topological symmetry to be obtained. It is of interest that the maximal symmetry for topologically quite similar chains in the structures of fermiite [ $\mathrm{a}_{\mathrm{a}} \mathrm{ma}$, Fig. 4(h)] and bobcookite [ $\mu_{\mathrm{a}}$ mam, Fig. 4(i)], in which the water molecule is replaced by the one-connected sulfate tetrahedron, differs as it is impossible to have more than two planes passing through the additional three non-shared tetrahedral vertices. It should be also noted that the lowest topological symmetry $\left[\mu_{\mathrm{a}} 112\right.$, Fig. $4(f)]$ among these 1D complexes has the chain in the structure of uranopilite.

The crystal structures of geschieberite, leydetite, magnesioleydetite, strassmannite and wetherillite are based upon the $\left[\left(\mathrm{UO}_{2}\right)\left(\mathrm{SO}_{4}\right)_{2}\left(\mathrm{H}_{2} \mathrm{O}\right)\right]^{2-}$ uranyl sulfate layers of the same topological type [Figs. 5(a) and 5(b)]. Being two-connected, all sulfate tetrahedra could rotate around this edge that result in various possible arrangements, and thus different LGs of symmetry. But all varieties are finally reduced to the maximal $c 2 m m$ LG. Fig. 5(a) illustrates the real pn symmetry of the 
uranyl sulfate layer in the structure of geschieberite. In total, there are 16 orbits with the twofold multiplicity (32 atoms in the reduced cell). Structural complexity parameters for the uranyl sulfate layer in the structure of geschieberite is calculated as $I_{G}=4.000$ bits per atom, $I_{G \text {,total }}=128.000$ bits per cell. The highest symmetry could be obtained if both unshared vertices of the sulfate tetrahedra were arranged one above another along the $c$ direction, so that the mirror plane would pass through the equatorial planes of uranyl bipyramids, resulting in twice reduced base-centered cell. In this case, the $v$ (number of atoms) is 16, and the distribution of orbits is as follows: one $\mathrm{U}$ orbit with multiplicity of 1 ; one $\mathrm{S}$ orbit with multiplicity of 2; one $\mathrm{O}_{U r}$ orbit with multiplicity of 2; three $\mathrm{O}_{S}$ orbits with multiplicities of 2, 2 and 4; one $\mathrm{O}_{\mathrm{H} 2 \mathrm{O}}$ orbit with multiplicity of 1 ; one $\mathrm{H}$ orbit with multiplicity of 2 . In total, there are two orbits with multiplicities of 1 , five orbits with

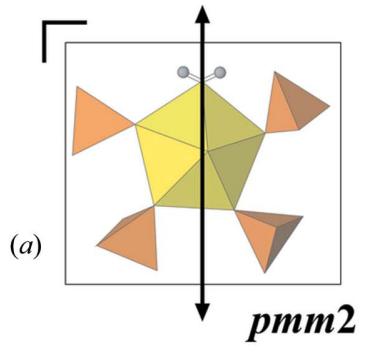

(d)

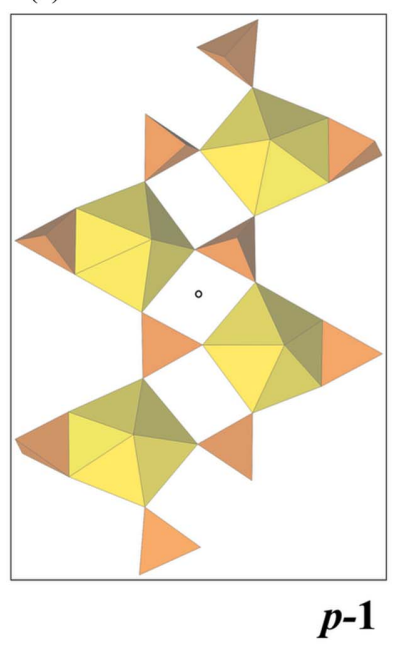

(g)

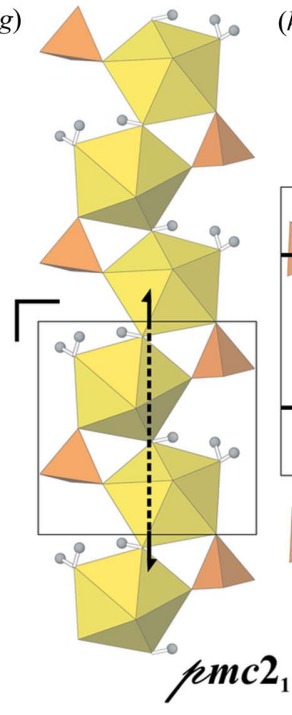

(b)

(h)

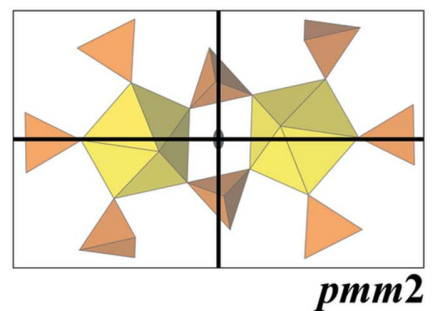

pmm2

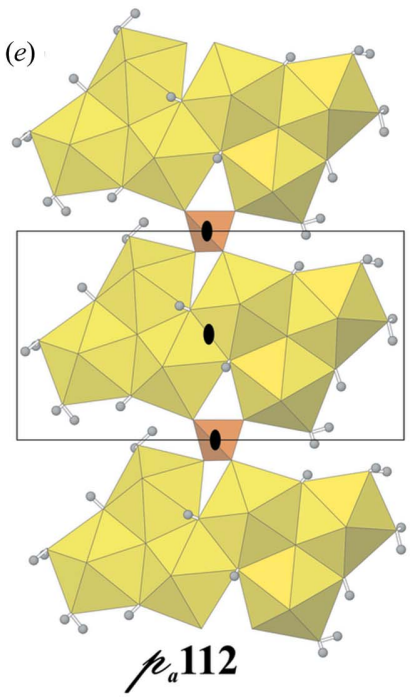

(i)

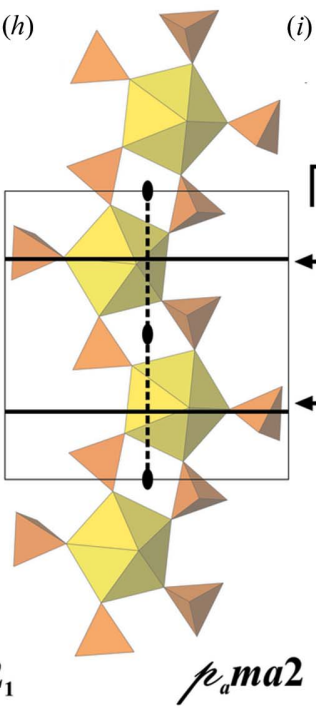

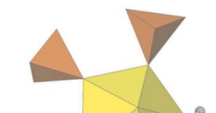

(c)
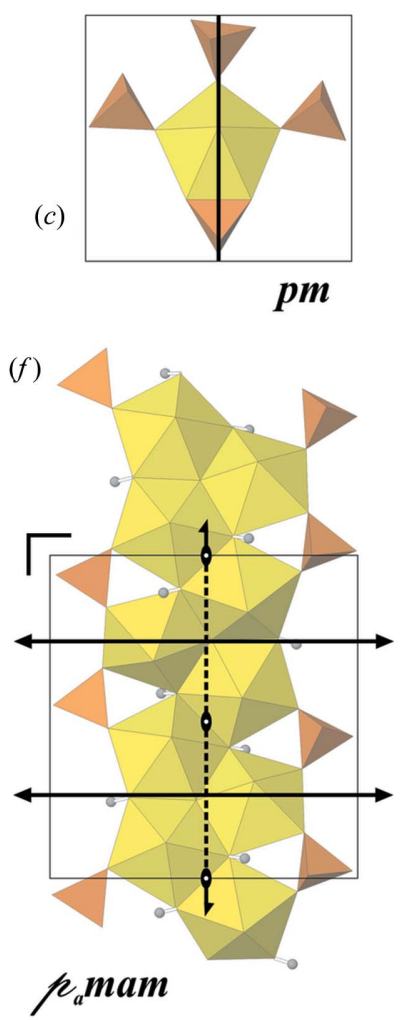

(j)

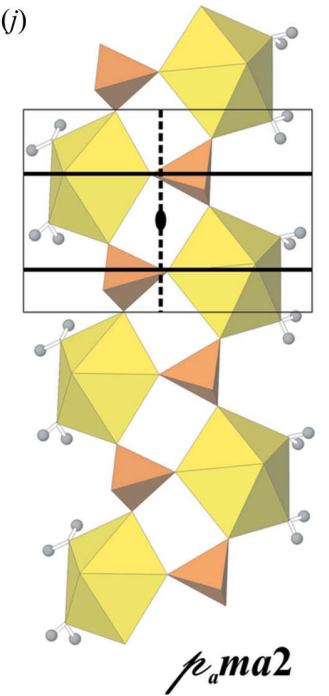

Figure 4

Lower dimensional structural units (0D and 1D) and their respective highest symmetry groups for $(a)$ belakovskiite, $(b)$ bluelizardite, $(c)$ klaprothite/ péligotite, $(d)$ ottohahnite, $(e)$ uranopilite, $(f)$ alwilkinsite- $(\mathrm{Y}),(g)$ adolfpateraite, $(h)$ fermiite/meisserite, $(i)$ bobcookite/oppenheimerite/rietveldite, $(j)$ shumwayite. Color scheme as in Fig. 3. 
multiplicities of 2 and one orbit with the multiplicity of 4 . The topological complexity parameters for the uranyl sulfate layer in the structures of geschieberite, magnesioleydetite and strassmannite are: $I_{\mathrm{G}}=2.875$ bits per atom, $I_{G \text {,total }}=46.000$ bits per cell. Another interesting point is the symmetry of uranyl sulfate layer in the structure of wetherillite, which is topologically identical to the structures described above. However, these layered complexes are distinct because of the different arrangement of $\mathrm{H}_{2} \mathrm{O}$ molecules (Fig. 5c) (see also Krivovichev et al., 2005; Krivovichev, 2008). Although the overall topology is the same, the current geometrical isomer will have another topological symmetry $p 2_{1} a m$ with twice the number of atoms in the reduced cell. The ideal topology for the geometrical isomers could be different (for details see references cited above).

More complex topology of the uranyl sulfate layer in the structure of beshtauite, with elongated 12-membered voids, results in an increased dimensionality of the reduced cell. But two-connected way of tetrahedra arrangement still keeps the high maximal pbam symmetry (Fig. $5 d$ ).

Crystal structures of deliensite, feynmannite, greenlizardite, johannite and meitnerite are based on the layered uranyl sulfate complexes of the same topological type. This type of topology has three-connected sulfate tetrahedra with the fourth non-shared vertex arranged up or down relative to the plane of the layer. This variability gives rise to geometric isomers with various orientations of the sulfate polyhedra (Krivovichev \& Burns, 2003; Krivovichev et al., 2005; Gurzhiy et al., 2015). To identify and classify the isomers of this topological type, their orientation matrices should be determined.
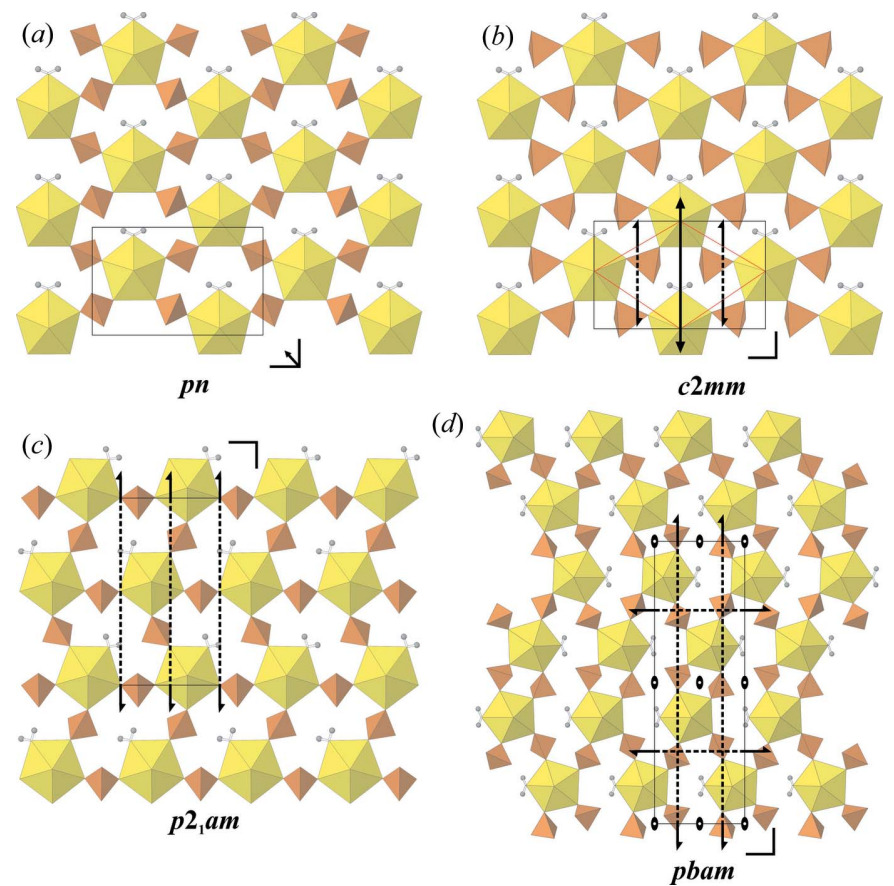

Figure 5

Structural sheets, symmetry elements and the respective layer group symmetries for ( $a$ ) geschieberite (real LG), (b) the highest LG for the same isomer, $(c)$ the highest LG for wetherillite and $(d)$ the highest LG for beshtauite. Color scheme as in Fig. 3.
According to this approach, the symbols $\mathbf{u}$ (up) or $\mathbf{d}$ (down) are assigned to each sulfate tetrahedron. As the result, three different geometric isomers have been determined, which has their individual maximal symmetry group. Johannite and meitnerite have the dudu sequence of vertices orientation and $c 2 / m$ LG symmetry (Fig. 6a). Layers in greenlizardite have the uuuu sequence of vertices orientation and $\mathrm{cmm} 2 \mathrm{LG}$ symmetry (Fig. 6b). Deliensite and feynmannite have the uddu orientation matrix and pmmn LG symmetry (Fig. 6c).

The presence of $\left(\mathrm{VO}_{5}\right)$ pyramids within the uranyl sulfate layers in the structures of mathesiusite and ammoniomathesiusite stabilizes the LG with the highest $p 4 / n$ structural and topological symmetries (Fig. $6 d$ ) among the natural uranyl sulfates (Table 2). Although the symmetry is high, there is one $\mathrm{U}$ orbit with multiplicity of 8 , one $\mathrm{S}$ orbit with multiplicity of 8 , one $\mathrm{V}$ orbit with multiplicity of 2 , one $\mathrm{O}$ orbit with multiplicity of 2 and seven $\mathrm{O}$ orbits with multiplicities of 8 , which results in $v=76$ and rather high complexity parameters for the uranyl sulfate layers in the structures of mathesiusite and ammoniomathesiusite: $I_{G}=3.353$ bits per atom, $I_{G \text {,total }}=$ 254.842 bits per cell.

Zippeite-group minerals can be considered as the most representative group among naturally occurring uranyl sulfates. Additionally, they represent also the trickiest ones due to a variable $\mathrm{OH}$ content of the layers and it has to be considered in topological complexity calculations as further discussed in detail. Among the hydroxyl-free layers, two

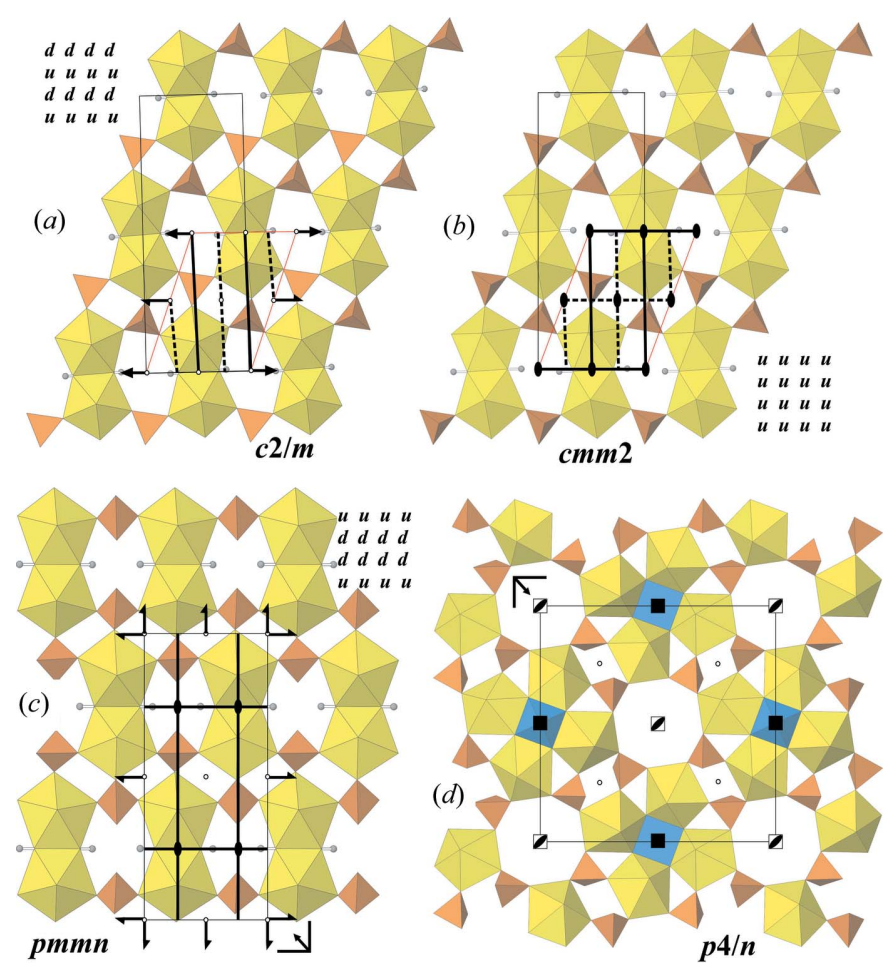

Figure 6

Structural sheets, symmetry elements, and the respective highest layer group symmetries for $(a)$ johannite, $(b)$ greenlizardite, $(c)$ deliensite and (d) mathesiusite. Color scheme as in Fig. 3; blue polyhedra $=\mathrm{VO}_{5}$ pyramids. 
groups of minerals could be separated due to geometrical isomerism that is caused by the shift of U-polyhedra chains along the chain direction. The first isomer group contains magnesiozippeite, plavnoite and pseudojohannite. They have the smallest reduced cell of the $p 2 / a$ LG symmetry, which is defined with the topological complexity parameters: $v=26, I_{G}$ $=2.777$ bits per atom, $I_{G, \text { total }}=72.211$ bits per cell. Further on, Figs. 7(a) and 7(b) show the real LG symmetry in the structures of magnesiozippeite and pseudojohannite, and the highest topological symmetry for hydroxyl-free layers of the currently considered isomer is shown in Fig. 7(c). The second geometrical isomer is represented by the structure of ammoniozippeite and its structural symmetry $p b a b$ is equal to the topological (Fig. 7f): $v=52, I_{G}=2.777$ bits per atom, $I_{G \text {,total }}$
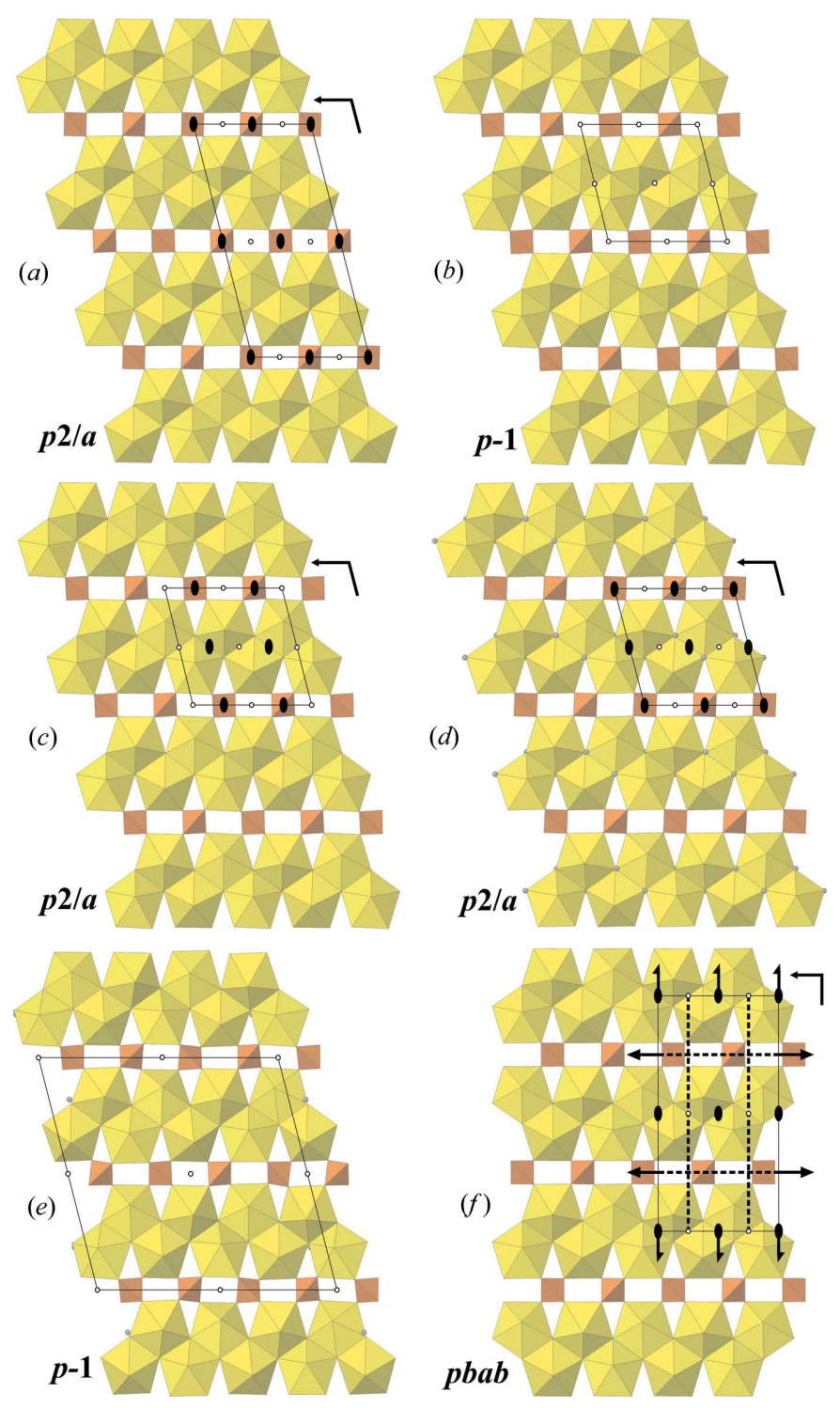

Figure 7

Structural sheets, symmetry elements and the respective layer group symmetries for zippeite-group minerals: (a) magnesiozippeite (real LG), (b) pseudojohannite (real LG), (c) holosymmetrical OH-free structure, (d) zippeite (the highest LG), (e) sejkoraite-(Y) (real LG) and (f) ammoniozippeite (the highest LG).
$=144.423$ bits per cell. While the values of information content per atom are equal for both isomers, information content per unit cell is twice as high for the second type due to the twice larger cell, it doubles the amount of atoms in the reduced cell. An appearance of hydroxyl groups strongly affects and reduces the symmetry of the layered complexes. Statistical distribution of $\mathrm{H}$ atoms in the structure of zippeite results in a 'hydroxyl-full', electroneutral $\left[\left(\mathrm{UO}_{2}\right)_{2}\left(\mathrm{SO}_{4}\right)(\mathrm{OH})_{2}\right]^{0}$ layer in contrast to the hydroxyl-free ones $\left[\left(\mathrm{UO}_{2}\right)_{2} \mathrm{O}_{2}\left(\mathrm{SO}_{4}\right)\right]^{2-}$. It appears that occupation of all $\mathrm{O}$ atoms shared between three uranyl polyhedra by $\mathrm{H}$ atoms will result in the same highest $p 2 / a$ LG symmetry (Fig. $7 d$ ), but slightly higher complexity parameters: $v=30, I_{G}=2.974$ bits per atom, $I_{G, \text { total }}=$ 89.207 bits per cell. All intermediate options of hydration could result in structurally and topologically different layers. For instance, Fig. 7(e) shows the uranyl sulfate layer of $p \overline{1}$ symmetry in the structure of sejkoraite-(Y). The four times larger reduced cell is a clear structural response to the $\mathrm{U}: \mathrm{OH}$ ratio equal to $8: 1$.

\section{Ladders of information}

A concept of informational ladders has been introduced quite recently by Krivovichev (2018). This method allows the quantitative estimation of various contributions to the complexity of the whole structure. We have applied this concept in order to evaluate and distinguish informational sources contributing to the complexity of natural uranyl sulfates. Let us consider a few low-dimensional, $0 \mathrm{D}$ and 1D structures, including minerals belakovskiite (0D), klaprothite (0D), péligotite (0D), ottohahnite (0D), alwilkinsite-(Y) (1D) and uranopilite (1D). We considered three distinct categories contributing to the information content of the entire structure: topological complexity (TOPO), complexity of the desymmetrized structural units (STRU) and the complexity of an interlayer complex, including a hydrogen bonding network (INT). Results of the analysis are given in Fig. 8. Among the

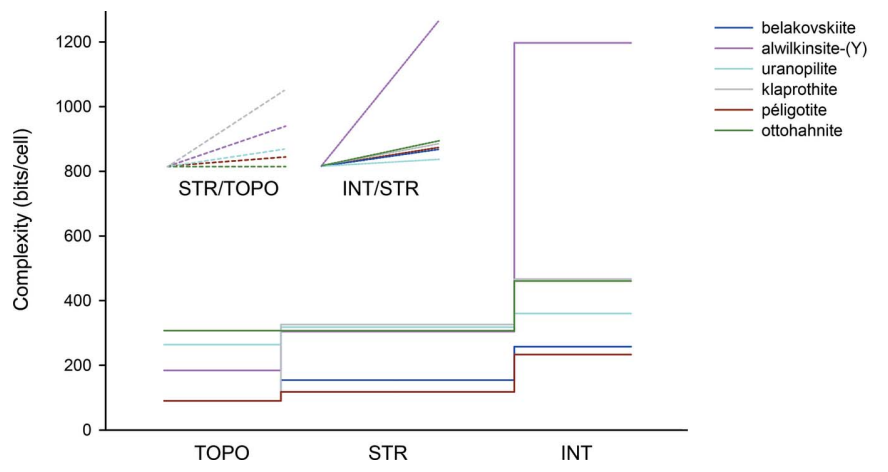

Figure 8

Ladder diagrams showing information growth for the crystal structures of the selected uranyl sulfate minerals (0D and $1 \mathrm{D}$ structures) due to contributions from different sources. TOPO $=$ topological information of the structural unit; STR = structural information resulting from desymmetrization of the basic structural unit; INT = information increase due to complexity of interlayer complex including hydrogen bonding network. Insets STR/TOPO and INT/STR represent an alternative graphical expression of the information increase. 
above-chosen representatives, the highest topological complexity has the structural unit in ottohahnite [Figs. 2 and $4(d)$ ], which is so far the most complex isolated uranyl-anion cluster unit (>300 bits per cell). Interestingly, péligotite and uranopilite show a similar portion of information increase while desymmetrization takes place (STR/TOPO in Fig. 8). Nevertheless, the highest jump in the information content is related to the contribution of the interlayer complex of these minerals. We can distinguish here several factors that contribute to the complexity of the interlayer. Among them the hydration state, i.e. the amount of molecular $\mathrm{H}_{2} \mathrm{O}$, is the most crucial factor. The $\mathrm{H}_{2} \mathrm{O}$ content is closely connected with the presence of highly charged elements [such as $\mathrm{Y}^{3+}$ in the case of alwilkinsite-(Y)], or due to presence of a large number of interlayer metal cation sites (such as $\mathrm{Na}^{+}$in the cases of ottohahnite and klaprothite). The remarkable informational content in alwilkinsite-( $\mathrm{Y})$ is the highest one among the selected group (see INT/SU in Fig. 8), and is a result of the incorporation of highly charged, trivalent yttrium cations.

The extensive role of the interstitial $\mathrm{H}_{2} \mathrm{O}$ network and its contribution to the overall complexity of the mineral structures containing highly charged cations is well documented in Fig. 9. Among the studied uranyl sulfates it is mostly related to alwilkinsite-( $\mathrm{Y}), \mathrm{Y}\left[\left(\mathrm{UO}_{2}\right)_{3}\left(\mathrm{SO}_{4}\right)_{2} \mathrm{O}(\mathrm{OH})_{3}\right]\left(\mathrm{H}_{2} \mathrm{O}\right)_{14}$ (Kampf $e t$ al., 2017c), bobcookite, $\mathrm{NaAl}\left(\mathrm{UO}_{2}\right)_{2}\left(\mathrm{SO}_{4}\right)_{4}\left(\mathrm{H}_{2} \mathrm{O}\right)_{18}$ (Kampf et al., 2015a), leydetite, $\mathrm{Fe}\left(\mathrm{UO}_{2}\right)\left(\mathrm{SO}_{4}\right)_{2}\left(\mathrm{H}_{2} \mathrm{O}\right)_{11}$ (Plášil et al., 2013a), magnesioleydetite, $\mathrm{Mg}\left(\mathrm{UO}_{2}\right)\left(\mathrm{SO}_{4}\right)_{2}\left(\mathrm{H}_{2} \mathrm{O}\right)_{11}$ (Kampf et al., 2018d) and strassmannite, $\mathrm{Al}\left(\mathrm{UO}_{2}\right)\left(\mathrm{SO}_{4}\right)_{2} \mathrm{~F}\left(\mathrm{H}_{2} \mathrm{O}\right)_{16}$ (Kampf et al., 2018d).

As it was mentioned above mathesiusite, ammoniomathesiusite and zippeite possess structures with the highest content of information with regard to their topological complexity (Fig. 9). In the cases of mathesiusite and ammoniomathesiusite, it is due to incorporation of $\mathrm{VO}_{5}$ polyhedra of the high point-group symmetry $\left(C_{4 v}\right)$. In the case of zippeite, it is due to distribution of the $\mathrm{OH}^{-}$groups within the uranyl sulfate sheet.

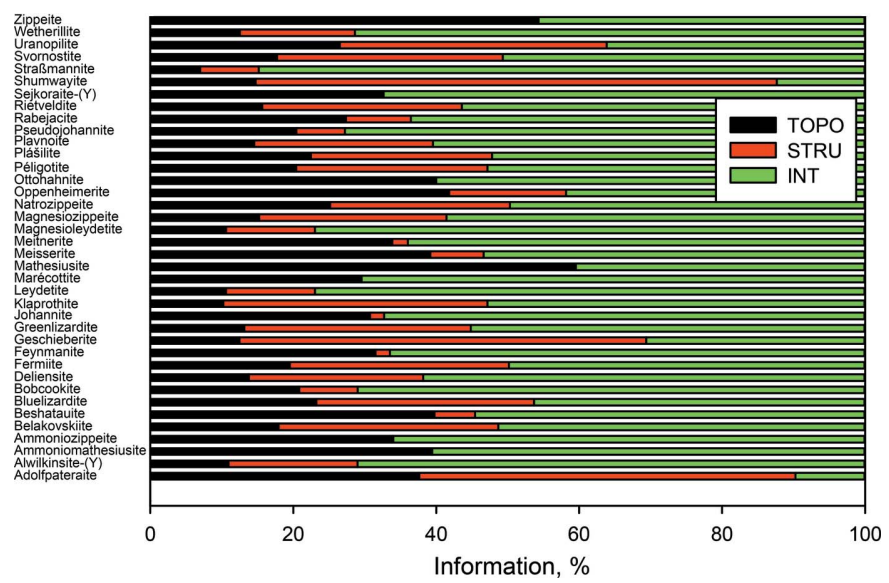

Figure 9

Information diagram for the crystal structures of natural uranyl sulfates listed in Table 2 showing the informational contribution from distinct sources (topology of structural units $=\mathrm{TOPO}$, desymmetrization $=$ STRU, interstitial complex $=$ INT).

\section{Conclusions}

The complexity of the uranyl sulfate structural units varies significantly and it is highly dependent on the relative density of the layer (chain or cluster), which in turn depends on the connectivity of $\mathrm{U}$ and $\mathrm{S}$ polyhedra: the more connectivity within the layer, the higher density is; and the larger complexity parameters attributed to such structures.

The two-connected arrangement of the sulfate tetrahedra makes the rotation of these groups, which should make the structure less stable. In contrast, the three-connected arrangement has fewer degrees of freedom, and thus it is more stable. The distribution of the complexity parameters confirms this observation. The majority of considered minerals have the real symmetry of the U-bearing layers, chains and isolated clusters much lower than the topological symmetry, which means that the complexity of the structural units is determined by the cations and $\mathrm{H}_{2} \mathrm{O}$ molecules arranged in the interlayer space.

\section{Acknowledgements}

We are indebted to referees for their constructive reviews that helped to improve this article.

\section{Funding information}

The following funding is acknowledged: This research was partially supported through the project Ministry of Education, Youth and Sports National sustainability program I of the Czech Republic (project No. LO1603 to JP); and through the grant of Russian Science Foundation (grant No. 18-17-00018 to Vladislav V. Gurzhiy).

\section{References}

Blatov, V. A., Shevchenko, A. P. \& Proserpio, D. M. (2014). Cryst. Growth Des. 14, 3576-3586.

Brugger, J., Burns, P. C. \& Meisser, N. (2003). Am. Mineral. 88, 676685.

Burns, P. C. (2001). Can. Mineral. 39, 1139-1146.

Burns, P. C., Deely, K. M. \& Hayden, L. A. (2003). Can. Mineral. 41, 687-706.

Cempírek, J., Grew, E. S., Kampf, A. R., Ma, C., Novák, M., Gadas, P., Škoda, R., Vašinová-Gáliová, M., Pezzotta, F., Groat, L. A. \& Krivovichev, S. V. (2016). Am. Mineral. 101, 2108-2117.

Fernandes, H. M., Veiga, L. H. S., Franklin, M. R., Prado, V. C. S. \& Taddei, J. F. (1995). J. Geochem. Explor. 52, 161-173.

Finch, R. J. \& Murakami, T. (1999). Uranium: Mineralogy, Geochemistry and the Environment, edited by P. C. Burns and R. J. Finch, in Reviews in Mineralogy, Vol. 38, pp. 91-179. De Gruyter.

Gurzhiy, V. V., Kovrugin, V. M., Tyumentseva, O. S., Mikhailenko, P. A., Krivovichev, S. V. \& Tananaev, I. G. (2015). J. Solid State Chem. 229, 32-40.

Gurzhiy, V. V., Krivovichev, S. V. \& Tananaev, I. G. (2017). J. Solid State Chem. 247, 105-112.

Gurzhiy, V. V., Tyumentseva, O. S., Britvin, S. N., Krivovichev, S. V. \& Tananaev, I. G. (2018a). J. Mol. Struct. 1151, 88-96.

Gurzhiy, V. V., Tyumentseva, O. S., Krivovichev, S. V., Krivovichev, V. G. \& Tananaev, I. G. (2016). Cryst. Growth Des. 16, 4482-4492. Gurzhiy, V. V., Tyumentseva, O. S., Krivovichev, S. V. \& Tananaev, I. G. (2018b). Z. Kristallogr. 233, 233-245.

Johnson, D. B. (2003). Water Air Soil Pollut. 3, 47-66. 
Johnson, D. B. \& Hallberg, K. B. (2005). Sci. Total Environ. 338, 3-14. Kampf, A. R., Kasatkin, A. V., Čejka, J. \& Marty, J. (2015a). J. Geosci. pp. $1-10$.

Kampf, A. R., Olds, T. A., Plášil, J., Marty, J. \& Perry, S. N. (2018c). Mineral. Mag. DOI: 10.1180/mgm.2018.117.

Kampf, A. R., Plášil, J., Čejka, J., Marty, J., Škoda, R. \& Lapčák, L. (2017c). Mineral. Mag. 81, 895-907.

Kampf, A. R., Plášil, J., Kasatkin, A. V. \& Marty, J. (2014). Mineral. Mag. 78, 639-649.

Kampf, A. R., Plášil, J., Kasatkin, A. V. \& Marty, J. (2015b). Mineral. Mag. 79, 695-714.

Kampf, A. R., Plášil, J., Kasatkin, A. V., Marty, J. \& Čejka, J. (2017b). Mineral. Mag. 81, 753-779.

Kampf, A. R., Plášil, J., Kasatkin, A. V., Marty, J. \& Čejka, J. (2015cb). Mineral. Mag. 79, 1123-1142.

Kampf, A. R., Plášil, J., Kasatkin, A. V., Marty, J., Čejka, J. \& Lapčák, L. (2017a). Mineral. Mag. 81, 273-285.

Kampf, A. R., Plášil, J., Kasatkin, A. V., Nash, B. P. \& Marty, J. (2018d). Mineral. Mag. DOI: 10.1180/mgm.2018.118.

Kampf, A. R., Plášil, J., Nash, B. P. \& Marty, J. (2017e). Mineral. Mag. 82, 401-411.

Kampf, A. R., Plášil, J., Nash, B. P. \& Marty, J. (2018a). Mineral. Mag. DOI: $10.1180 / \mathrm{mgm} .2018 .112$.

Kampf, A. R., Plášil, J., Nash, B. P. \& Marty, J. (2018e). Eur. J. Mineral. 30, 999-1006.

Kampf, A. R., Plášil, J., Olds, T. A., Nash, B. P. \& Marty, J. (2018b). Can. Mineral. 56, 235-245.

Kampf, A. R., Sejkora, J., Witzke, T., Plášil, J., Čejka, J., Nash, B. P. \& Marty, J. (2017d). J. Geosci. 62, 107-120.

Krivovichev, S. V. (2008). Structural Crystallography of Inorganic Oxysalts, p. 308. Oxford University Press.

Krivovichev, S. V. (2010). Eur. J. Inorg. Chem. 2010, 2594-2603.

Krivovichev, S. (2012). Acta Cryst. A68, 393-398.

Krivovichev, S. V. (2013). Mineral. Mag. 77, 275-326.

Krivovichev, S. V. (2014). Angew. Chem. Int. Ed. 53, 654-661.

Krivovichev, S. V. (2018). Z. Kristallogr. 233, 155-161.

Krivovichev, S. V. \& Burns, P. C. (2003). Z. Kristallogr. 218, 683-690.

Krivovichev, S. V., Kahlenberg, V., Tananaev, I. G. \& Myasoedov, B. F. (2005). Z. Anorg. Allg. Chem. 631, 2358-2364.

Krivovichev, S. V., Hawthorne, F. C. \& Williams, P. A. (2017). Struct. Chem. 28, 153-159.

Krivovichev, S. V. \& Plášil, J. (2013). In: Uranium: From Cradle to Grave, edited by P. C. Burns and G. E. Sigmon. MAC Short Courses series, Vol. 43, pp. 15-119. Mineralogical Association of Canada.

Krivovichev, S. V., Zolotarev, A. A. \& Popova, V. I. (2016). Struct. Chem. 27, 1715-1723.
Majzlan, J., Dachs, E., Benisek, A., Plášil, J. \& Sejkora, J. (2018). Eur. J. Mineral. 30, 259-275.

Mereiter, K. (1982). TMPM Tschermaks Mineral. Petrogr. Mitt. 30, 47-57.

Pekov, I. V., Krivovichev, S. V., Yapaskurt, V. O., Chukanov, N. V. \& Belakovskiy, D. I. (2014). Am. Mineral. 99, 1783-1787.

Plášil, J. (2014). J. Geosci. 59, 99-114.

Plášil, J. (2018a). Eur. J. Mineral. 30, 237-251.

Plášil, J. (2018b). Eur. J. Mineral. 30, 253-257.

Plášil, J., Dušek, M., Čejka, J. \& Sejkora, J. (2014c). Mineral. Mag. 57, 1249-1263.

Plášil, J., Dušek, M., Novák, M., Čejka, J., Císařová, I. \& Škoda, R. (2011a). Am. Mineral. 96, 983-991.

Plášil, J., Fejfarová, K., Škoda, R., Dušek, M., Marty, J. \& Čejka, J. (2013c). Mineral. Petrol. 107, 211-219.

Plášil, J., Fejfarová, K., Wallwork, K. S., Dušek, M., Škoda, R., Sejkora, J., Čjka, J., Veselovský, F., Hloušek, J., Meisser, N. \& Brugger, J. (2012c). Am. Mineral. 97, 1796-1803.

Plášil, J., Hauser, J., Petř́ícek, V., Meisser, N., Mills, S. J., Škoda, R., Fejfarová, K., Cejka, J., Sejkora, J., Hloušek, J., Johannet, J.-M., Machovič, V. \& Lapčák, L. (2012b). Mineral. Mag. 76, 28372860.

Plášil, J., Hloušek, J., Kasatkin, A. V., Novák, M., Čejka, J. \& Lapčák, L. (2015a). J. Geosci. 60, 113-121.

Plášil, J., Hloušek, J., Kasatkin, A. V., Škoda, R., Novák, M. \& Čejka, J. (2015b). Mineral. Mag. 79, 205-216.

Plášil, J., Hloušek, J., Veselovský, F., Fejfarová, K., Dušek, M., Škoda, R., Novák, M., Čejka, J., Sejkora, J. \& Ondruš, P. (2012a). Am. Mineral. 97, 447-454.

Plášil, J., Kampf, A. R., Kasatkin, A. V. \& Marty, J. (2014a). J. Geosci. 59, 145-158.

Plášil, J., Kampf, A. R., Kasatkin, A. V., Marty, J., Škoda, R., Silva, S. \& Čejka, J. (2013b). Mineral. Mag. 77, 2975-2988.

Plášil, J., Kasatkin, A. V., Škoda, R., Novák, M., Kallistová, A., Dušek, M., Skála, R., Fejfarová, K., Cejka, J., Meisser, N., Goethals, H., Machovič, V. \& Lapčák, L. (2013a). Mineral. Mag. 77, 429441.

Plášil, J., Mills, S. J., Fejfarová, K., Dušek, M., Novák, M., Škoda, R., Čejka, J. \& Sejkora, J. (2011b). Can. Mineral. 49, 1089-1103.

Plášil, J., Škácha, P., Sejkora, J., Kampf, A. R., Škoda, R., Čejka, J., Hloušek, J., Kasatkin, A. V., Pavlíček, R. \& Babka, K. (2017). Eur. J. Mineral. 29, 117-128.

Plášil, J. \& Škoda, R. (2015). Mineral. Mag. 79, 649-660.

Plášil, J., Veselovský, F., Hloušek, J., Škoda, R., Novák, M., Sejkora, J., Cejka, J., Škacha, P. \& Kasatkin, A. V. (2014b). Am. Mineral. 99, 625-632. 